\title{
Comparative ultrastructure of hatched human, mouse and bovine blastocysts
}

\author{
Linda R. Mohr and A. O. Trounson \\ Department of Obstetrics and Gynaecology, Monash University, Queen Victoria Medical \\ Centre, 172 Lonsdale Street, Melbourne, Australia 3000
}

\begin{abstract}
Summary. A hatched human blastocyst obtained after in-vitro fertilization and culture was examined by transmission electron microscopy and the ultrastructural features compared with hatched mouse and bovine blastocysts. The human blastocyst contained a continuous layer of trophoblast cells with apical junctional complexes, an inner cell mass and the beginning of a primitive endoderm layer. Certain ultrastructural features were common to the blastocysts of all 3 species; these included characteristic junction regions between adjacent trophoblast cells, an abundance of microvilli on the external surfaces of the blastocysts and the presence of well developed mitochondria and numerous ribosomes in the trophoblast cells. The features that were dissimilar included the extent of development of the endoderm layer, the appearance of the inner cell mass and the nature and extent of vesicular inclusions in the trophoblast cells.
\end{abstract}

\section{Introduction}

The blastocyst stage of preimplantation development is well characterized for a large number of mammalian species and certain morphological changes accompanying blastocyst formation are common within these species (Blandau, 1971). Before contact between embryonic and maternal cells blastocysts escape from the surrounding zona pellucida and are then referred to as hatched biastocysts. The ultrastructure of mouse blastocysts has been described from the time of cavity formation until the initial stage of implantation (Nadijcka \& Hillman, 1974) but no detailed reports on the fine structure of human or bovine hatched blastocysts are available.

The technique of in-vitro fertilization and embryo culture is capable of producing normal infants in the natural (Edwards, Steptoe \& Purdy, 1980; Lopata, Johnston, Hoult \& Speirs, 1980 ) and the stimulated (Trounson, Leeton, Wood, Webb \& Wood, 1981) ovulatory cycle of women. The correct culture conditions for producing viable embryos are important and, until a pregnancy is established, fertilization and preimplantation embryo growth are the only characteristics which can be used to assess the adequacy of the culture conditions. Expanded and hatched human blastocysts have been reported after in-vitro fertilization and culture (Steptoe, Edwards \& Purdy, 1971; Edwards, 1973; Trounson, Leeton, Wood, Webb \& Kovacs, 1980; Trounson, Mohr, Wood \& Leeton, 1982). Observation of cleavage, blastocyst formation or hatching can only give limited information on the developmental stage attained by the embryo. When mouse embryos are cultured for $96 \mathrm{~h}$ in vitro they form expanded blastocysts which appear, at low magnification, similar to blastocysts of the same age grown in vivo. Ultrastructurally, however, in-vitro cultured blastocysts show no development of endoderm cells 
although endoderm is observed in embryos grown in vivo (McReynolds \& Hadek, 1972). Because of the difficulties of obtaining human blastocysts fertilized and grown in vivo, human blastocysts resulting from in-vitro fertilization and culture can only be compared to blastocysts of other species. It has been suggested such a comparison may yield information on the metabolic requirements of human blastocysts and assist the development of optimal culture conditions for advanced human embryos (Grant, Nilsson \& Bergstrom, 1977).

The purpose of this investigation was (1) to study in detail the fine structure of a hatched human blastocyst produced from fertilization and culture in vitro, and (2) to compare the structure of this blastocyst with hatched mouse and bovine blastocysts.

\section{Materials and Methods}

The human blastocyst resulted from an oocyte recovered at laparoscopy from a patient whose ovulatory cycle was controlled with clomiphene citrate and hCG as described by Trounson $e t a l$. $(1981,1982)$. The oocyte was matured, inseminated and cultured in Hams F10 medium supplemented with $25.52 \mathrm{mg}$ calcium lactate $\cdot 1 \frac{1}{2} \mathrm{H}_{2} \mathrm{O}, 7.5 \mathrm{mg}$ penicillin $\mathrm{G}, 7.5 \mathrm{mg}$ streptomycin sulphate and $500 \mathrm{mg}$ human serum albumin (Sigma, crystallized and freeze dried) per $100 \mathrm{ml}$ medium. The oocyte was washed in follicular fluid and matured for $4 \mathrm{~h}$ in $1.0 \mathrm{ml}$ culture medium before insemination with approximately $1 \times 10^{6}$ motile spermatozoa per ml. After $18 \mathrm{~h}$ the oocyte contained two pronuclei and was then transferred to $1.0 \mathrm{ml}$ fresh medium for the duration of culture. The embryo was at the 4-cell stage by $56 \mathrm{~h}$ and at 8 cells by $76 \mathrm{~h}$ after insemination. A hatched blastocyst was recovered $140 \mathrm{~h}$ after insemination and fixed for electron microscopy.

Mouse blastocysts were obtained from random bred Swiss Albino mice induced to superovulate with 5 i.u. PMSG (Folligon: Intervet Ltd) followed 48 h later by 5 i.u. hCG (Chorulon: Intervet Ltd). Early blastocysts were flushed out of the uterine horns 80-85 h after hCG injection. These blastocysts were cultured for $24 \mathrm{~h}$, using methods previously described (Mohr \& Trounson, 1980), and then hatching and hatched blastocysts were recovered and fixed for electron microscopy.

Bovine blastocysts were obtained by non-surgical flushing, 7 days after oestrus, of dairy cows induced to superovulate (Brand, Trounson, Aarts, Drost \& Zaayer, 1978). These blastocysts were cultured in modified Whitten's media (Hoppe \& Pitts, 1973) supplemented with $20 \%$ fetal calf serum using methods previously described (Mohr \& Trounson, 1981). After $24 \mathrm{~h}$, hatching and hatched blastocysts were recovered and fixed for electron microscopy.

Embryos were fixed in $3 \%$ glutaraldehyde in $0.1 \mathrm{M}$-cacodylate buffer with $1.25 \mathrm{~g} \mathrm{CaCl}_{2} / 1$, postfixed in $2 \%$ osmium tetroxide, dehydrated and embedded in an epon-araldite mixture. Sections for light microscopy were stained with $1 \%$ toluidine blue and examined with a Zeiss Photomicroscope III. Thin sections for electron microscopy were stained with uranyl acetate and lead citrate and examined in a Siemens I electron microscope at $80 \mathrm{kV}$.

\section{Results}

\section{General observations}

The blastocysts of all three species, when observed by the light microscope, contained a single layer of trophoblast cells which surrounded a cavity and into which protruded a disc-shaped group of cells, the inner cell mass. In the mouse blastocyst, a layer of endoderm cells was present overlying the ICM and had begun to migrate around the inside of the blastocoele. A primitive endoderm layer was visible in the human blastocyst but no endoderm was detectable 
PLATE 1
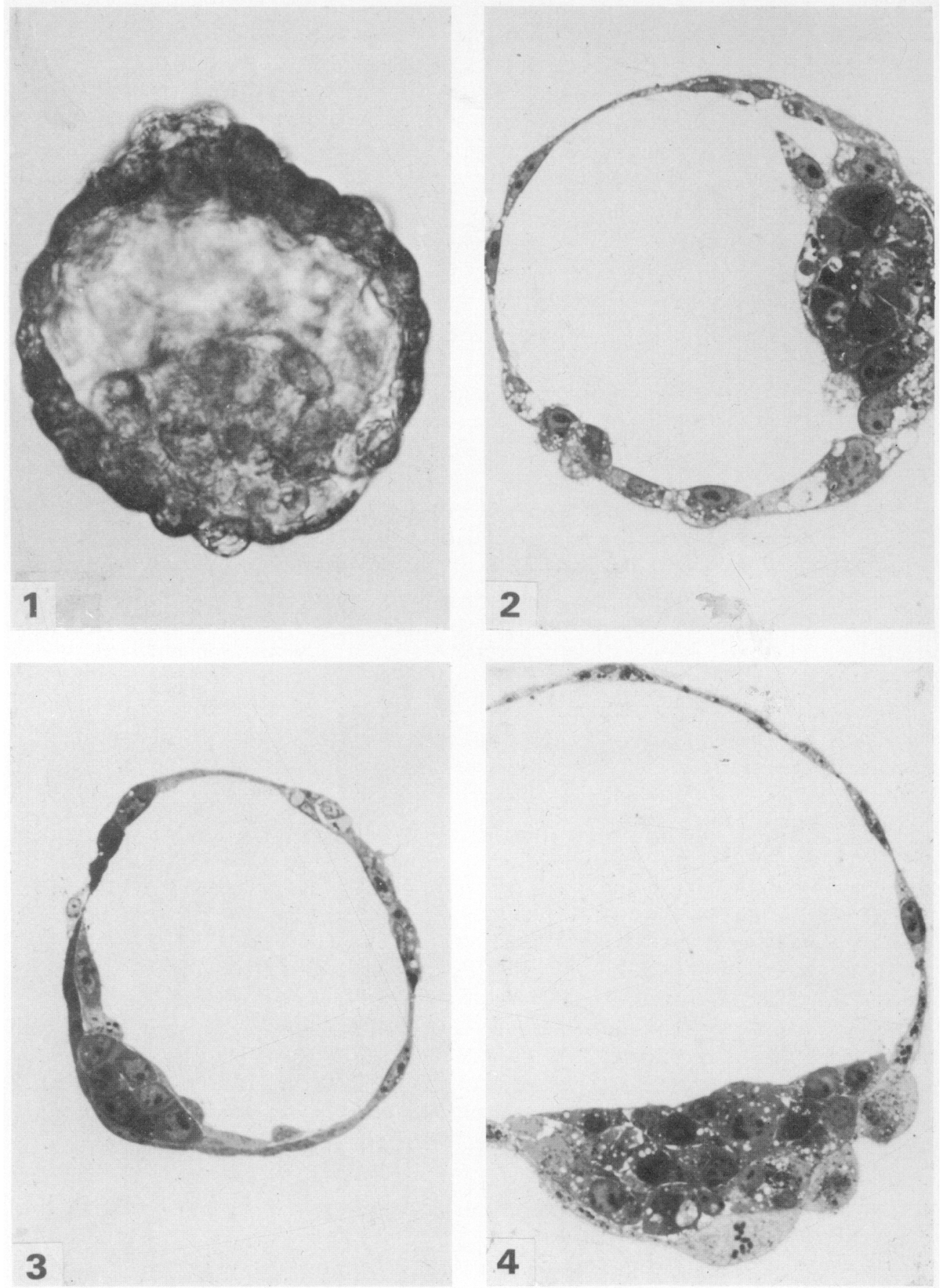

Fig. 1. A hatched human blastocyst recovered $140 \mathrm{~h}$ after insemination. $\times 600$.

Figs 2-4. Light micrographs of hatched human (Fig. 2), mouse (Fig. 3) and cow (Fig. 4) blastocysts. $\times 1000$. 

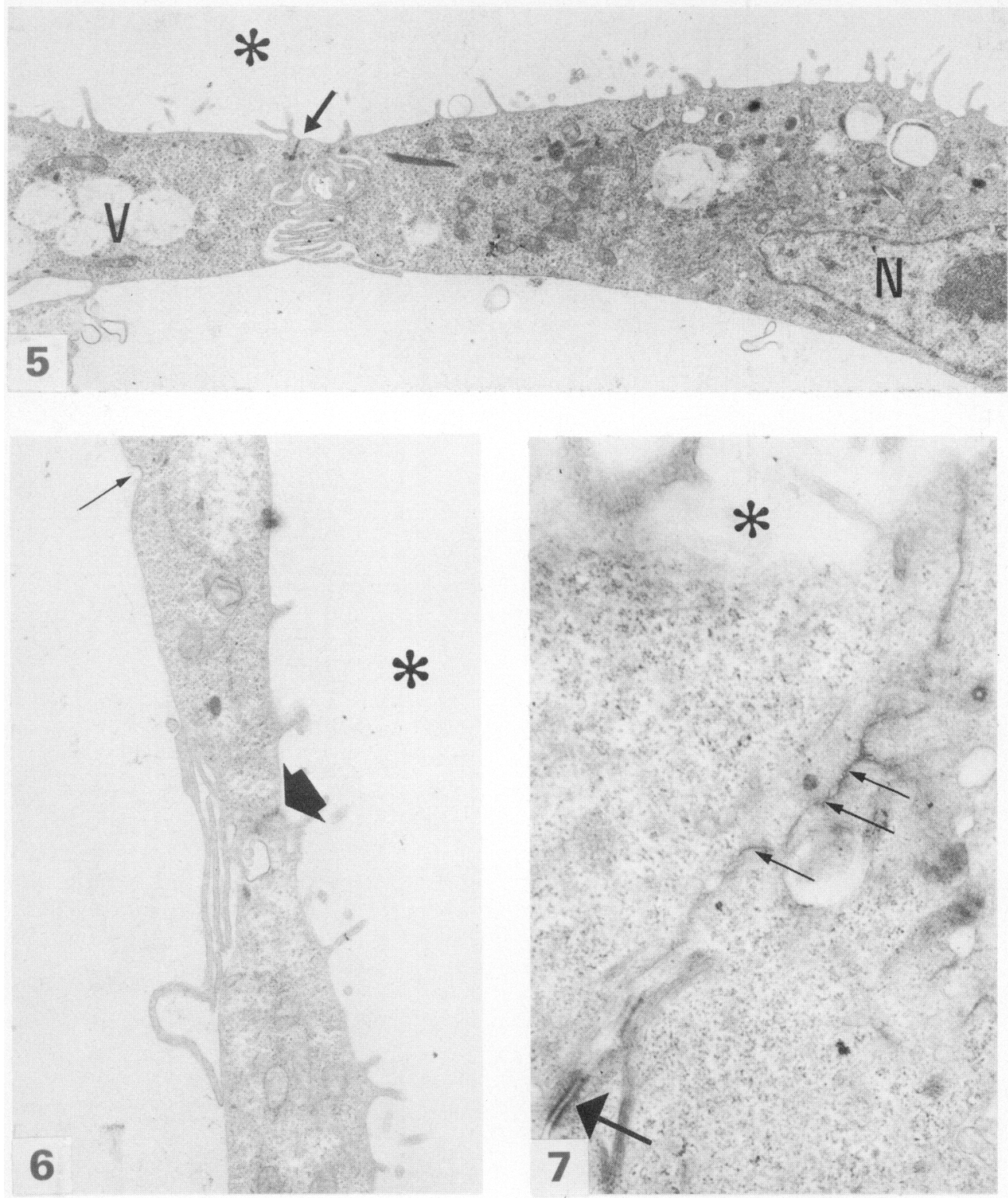

Figs 5-7. Electron micrographs showing cavity trophoblast cells in the human blastocyst. * indicates the external surface.

Fig. 5. Note the microvilli on the external surface. V, vesicles; $N$, nucleus; arrow indicates junction region. $\times 6000$.

Fig. 6. Note the cytoplasmic processes in the junction region. Thick arrow indicates junction region, thin arrow indicates pinocytotic activity. $\times 6000$.

Fig. 7. Junction region between two trophoblast cells. Note the focal fusions of the plasma membrane (thin arrows) and the desmosome-like junction (thick arrow). $\times 21000$. 
PLATE 3
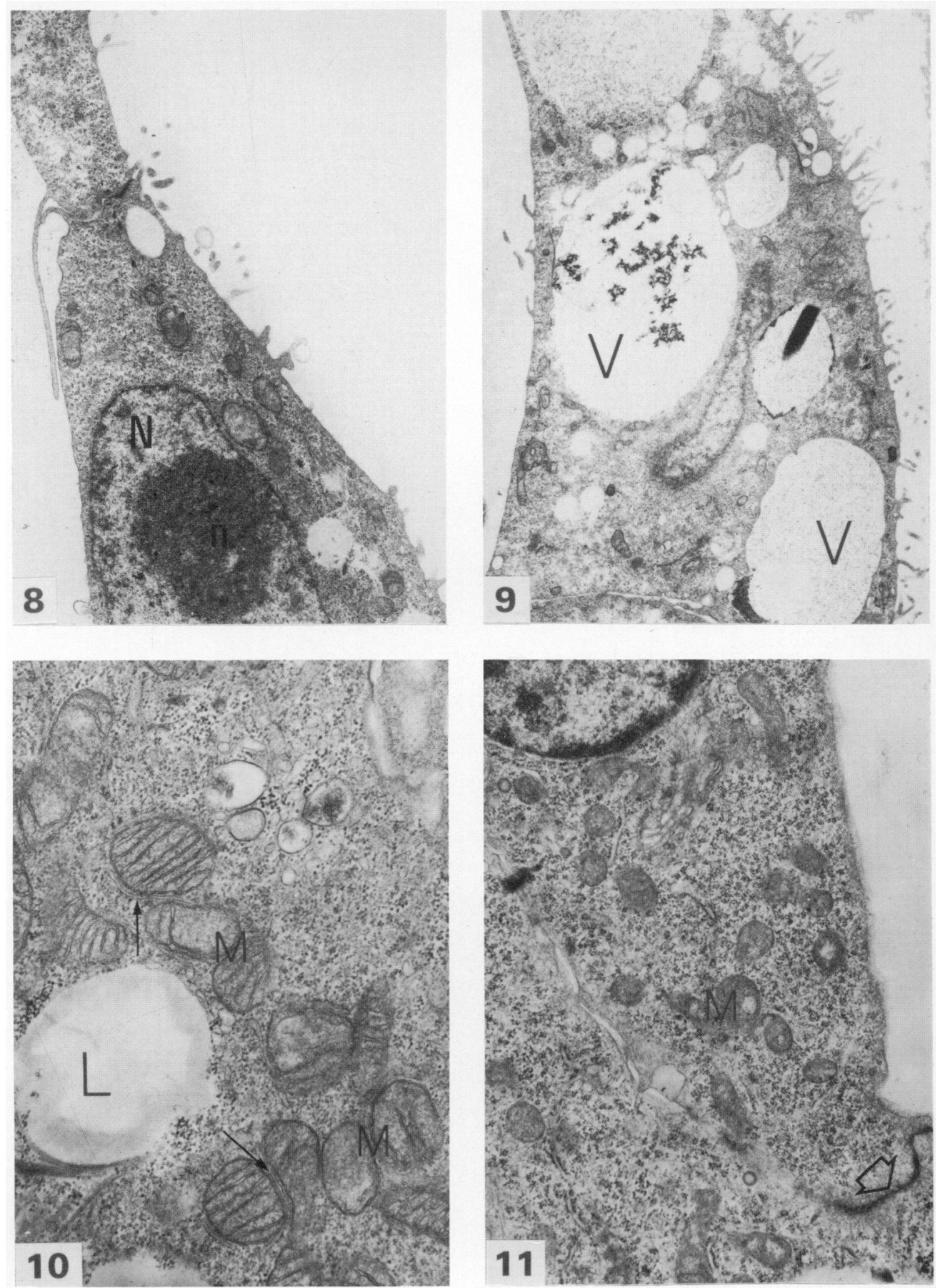


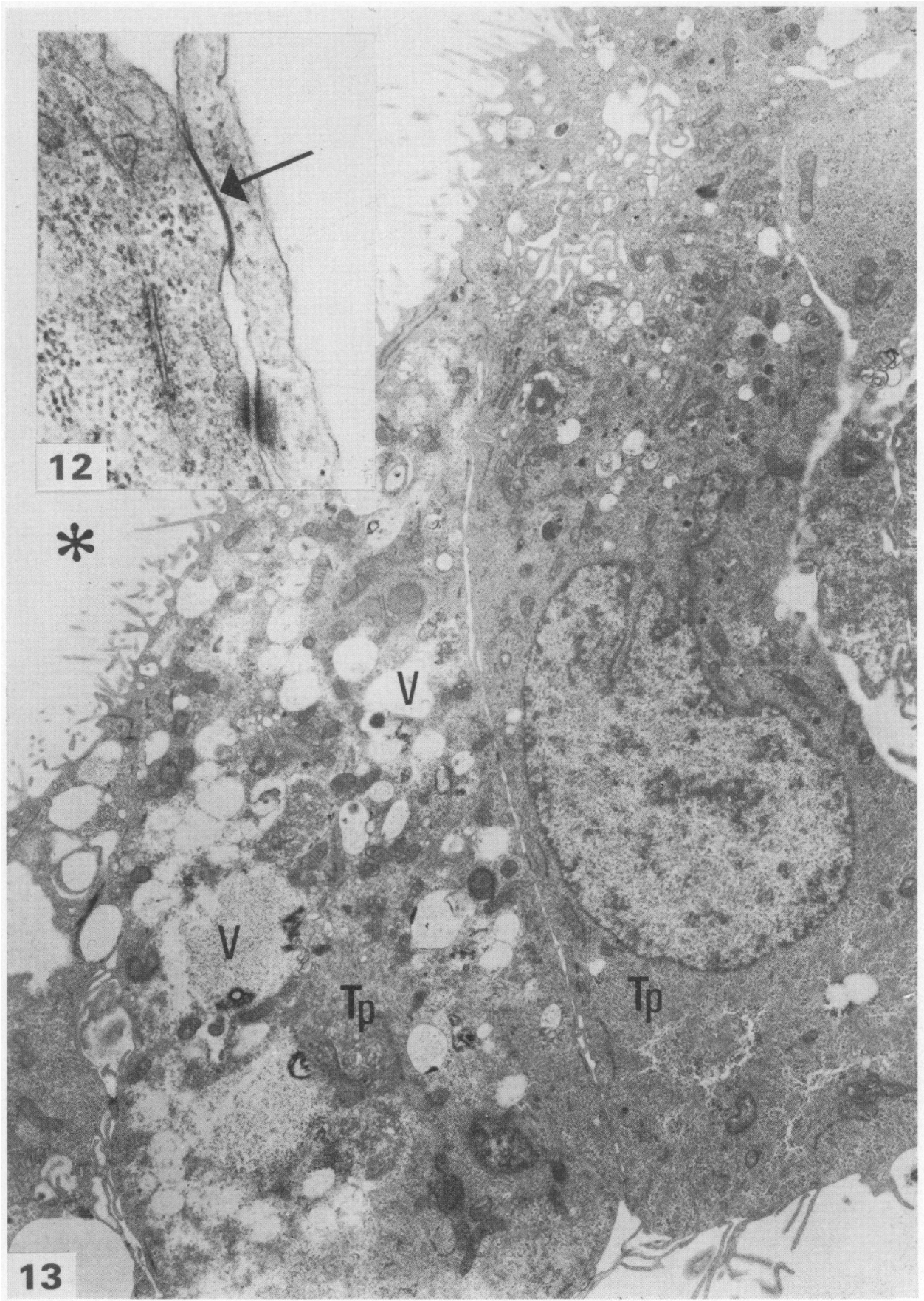

Fig. 12. Gap junction (arrow) between the process of one polar trophoblast cell and the plasma membrane of another. $\times 7500$.

Fig. 13. Electron micrograph showing polar trophoblast cells (Tp) in the human blastocyst. Note the cuboidal shape of the cells. long microvilli on the external surface and numerous vesicular inclusions $(\mathrm{V}) . \times 8000$. 


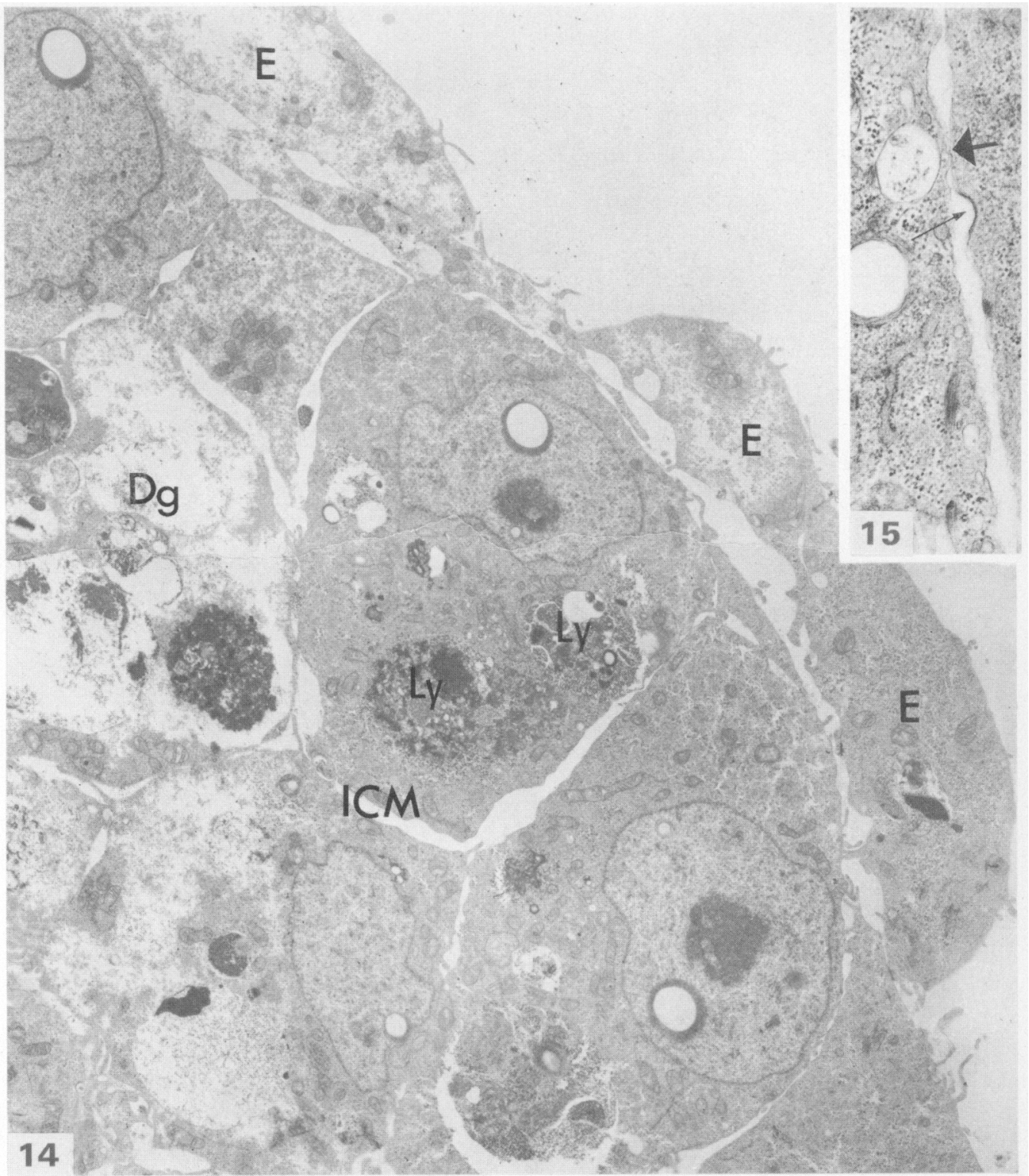

Fig. 14. Electron micrograph of a portion of the inner cell mass (ICM) and endoderm layer (E) in the human blastocyst. Note the degenerating cells in the ICM (Dg) and the lysosome-like structures $(\mathrm{Ly})$ in some ICM cells. $\times 7000$.

Fig. 15. Two ICM cells in the human blastocyst. Note the point of close contact between the two cells and pinocytotic activity (arrow). $\times 34500$. 
in the bovine blastocyst (Pl. 1, Figs 1-4). In the human and bovine blastocysts, the trophoblast cells surrounding the blastocoele appeared thin and attenuated while those in the region of the inner cell mass (polar trophoblast) appeared larger and more cuboidal. Mitotic cells were frequently encountered in the polar trophoblast. No giant cell transformation or syncytiotrophoblast differentiation was observed.

\section{Trophoblast cells}

Cavity trophoblast (mural trophoblast). The cavity trophoblast cells in all three species were characterized by extensive apical junctions between adjacent cells. Near the junction region, the inner surface of the trophoblast cells displayed numerous cytoplasmic processes (PI. 2, Figs 5 and 6). The junction regions comprised a tight junction on the outer surface followed by numerous desmosome-like junctions (Pl. 2, Fig. 7). Cavity trophoblast cells were polarized with respect to internal and external surfaces. The inner surface was relatively smooth with microvilli only near junction regions, cytoplasmic blebs protruding into the blastocoele and evidence of micropinocytotic activity were frequently seen (PI. 2, Fig. 6). The outer surface of the trophoblast cells in all three species contained numerous long microvilli. In all three species cavity trophoblast nuclei were centrally located and well differentiated with large nucleoli containing fibrillar and granular areas. Heterochromatin formed an irregular outline along the inner nuclear membranes and nuclear pores were frequent (Pl. 3, Fig. 8).

Intracellular organelles included numerous free ribosomes and ribosome clusters, rough and smooth endoplasmic reticulum, mitochondria, microfilament bundles and vesicular inclusions. In the human and bovine blastocysts vesicular inclusions were abundant in many trophoblast cells. Some of these inclusions contained lipid-like material while others contained granular or dense material (Pl. 3, Fig. 9). Mitochondria in the human cavity trophoblast were elongated, moderately electron dense with transverse cristae and were generally peripherally located (Pl. 3, Fig. 10). Smooth endoplasmic reticulum was frequently found in close association with mitochondria (Pl. 3, Fig. 10). Mitochondria in the mouse cavity trophoblast were smaller, vacuolated and comparatively more electron dense (Pl. 3, Fig. 11). Glycogen granules were a prominent feature in most cells of the human blastocyst (Pl. 3, Fig. 10).

Polar trophoblast. In the human and bovine blastocysts, polar trophoblast cells were less attenuated than cavity trophoblast, contained many vesicular inclusions, numerous long microvilli on the external surface (Pl. 4, Fig. 13) and were frequently mitotic (PI. 1, Fig. 4). They formed desmosome-like junctions with adjacent inner cell mass cells. The inner surface of the polar trophoblast was relatively smooth with a few long processes which terminated in gap junctions at adjacent polar trophoblast or inner cell mass cells ( $\mathrm{Pl}$. 4, Fig. 12). In the human blastocyst, there was an increase in size and number of vesicular inclusions in polar trophoblast cells compared with cavity trophoblast.

\section{PLATE 3}

Fig. 8. Electron micrograph showing human cavity trophoblast cells. Note the reticulated nucleus $(\mathrm{N})$ showing a prominent nucleolus $(\mathrm{n})$ and chromatin near the nuclear membrane. $x$ 6000 .

Fig. 9. Electron micrograph showing vesicular inclusions in a human trophoblast cell. Note the granular nature of the vesicular contents and the large size of some vesicles. $\times 5000$.

Fig. 10. Electron micrograph showing the mitochondria in a human trophoblast cell. Note the electron-translucent mitochondria and the close association of smooth endoplasmic reticulum (arrows). M, mitochondria; L, lipid droplet. $\times 24000$.

Fig. 11. Electron micrograph showing the small often vacuolated mitochondria in a mouse trophoblast cell. Arrow indicates junction region; M, mitochondria. $\times 35000$. 


\section{Inner cell mass}

The inner cell mass in all three species consisted of a disc of cuboidal cells joined to one another and to the adjacent trophoblast by desmosome junctions. In the mouse, these cells were closely apposed while in the human and bovine embryos, clefts of extracellular space were observed between adjacent cells (Pl. 5, Fig. 14). At some points the plasma membrane of adjacent inner cell mass cells were very closely apposed and micropinocytotic activity could be seen along the surface of the cells (Pl. 5, Fig. 15). There were degenerating cells in the inner cell mass of the bovine and human blastocysts (Pl. 5, Fig. 14). In the human and mouse, the nuclei of inner cell mass cells were large and irregular while those in the bovine blastocyst were spherical; the nuclei of all three species contained dense nucleoli (Pl. 1, Figs 2-4). Inner cell mass cells appeared darker than the neighbouring trophoblast (Pl. 1, Figs 2 and 4) or endoderm cells due to an increase in the number of free ribosomes. Other structures common to the cells of the inner cell mass of all three species include rough endoplasmic reticulum, spherical or oval mitochondria with transverse cristae and lysosome-like structures. The human cells also contained annulate lammellar structures, Golgi apparatus and glycogen.

\section{Endoderm}

Primitive endoderm was present in the mouse hatched blastocysts. These cells were located as a single continuous layer overlying the inner cell mass, adjoining polar trophoblast and migrating around the inside of the blastocoele cavity. Endoderm cells were joined to one another by apical desmosome-like junctions. They were joined to the underlying inner cell mass cells by gap junctions but formed no junctions with underlying trophoblast. These cells contained numerous branching channels of rough endoplasmic reticulum with distended cisternae containing electron-dense material. In some regions flocculent extracellular accumulations could be seen between the endoderm layer and the inner cell mass cells indicating the beginning of basement membrane formation.

In the human blastocyst, a distinct layer of cells was present overlying the inner cell mass. These cells formed apical desmosome-like junctions with one another and formed gap junctions with underlying inner cell mass cells. These cells did not form a complete layer over the inner cell mass and had not begun to migrate around the blastocoele (Pl. 5, Fig. 14).

In the bovine blastocyst no endoderm layer was evident from light microscopic examination but electron microscopy revealed that cells on the blastocoelic surface of the inner cell mass showed certain ultrastructural differences from the cells located beneath. These features include a flattening of the cells, an increased number of free ribosomes, the development of apical junctional regions and the appearance of small amounts of rough endoplasmic reticulum with dilated cisternae.

\section{Discussion}

The cleavage times recorded for the human blastocyst in vitro in this study are well within normal cleavage times recorded for human embryos in vitro (Edwards, 1973, 1980) and for viable human embryos that have implanted in the uterus after transfer (Trounson et al., 1982). The general light microscopic appearance of the blastocyst was similar to that of other human blastocysts reported (Steptoe et al., 1971; Edwards, 1973, 1980). The size of the blastocyst when photographed was smaller than when recovered from Ham's F10 medium. The blastocyst was transferred to a phosphate-buffered solution for photography and notable constriction of the blastocyst occurred within minutes of its immersion in the phosphate buffer.

The mouse and bovine blastocysts were cultured for $24 \mathrm{~h}$ to facilitate the recovery of just 
hatched blastocysts. This would not be expected to alter their ultrastructure as mouse embryos cultured for $26 \mathrm{~h}$ do not differ from embryos recovered at the same stage of development in vivo (McReynolds \& Hadek, 1972). The culture of embryos in vitro is known to alter embryo metabolism (Ozias \& Stern, 1973), and to diminish embryo viability, as assessed by implantation after transfer, as the period in culture is increased (Tervit \& Rowson, 1974). Increased amounts of glycogen have been observed in embryos cultured in vitro (Pike, 1981) and glycogen granules were a prominent feature in the cytoplasm of both the trophoblast and inner cell mass cells in the human blastocyst.

Vesicular inclusions and lysosome-like structures are common in the blastocysts of many mammalian species (Enders, 1971), they are particularly abundant in the late blastocysts of the sheep (Wintenberger-Torrès \& Fléchon, 1974) and cow (Mohr \& Trounson, 1981). The presence of lysosome-like organelles, autophagic vacuoles and degenerating cells, as described here in the inner cell mass of the human blastocyst, have also been reported in the inner cell mass of hatched primate blastocysts (Hurst, Jefferies, Eckstein \& Wheeler, 1978) and indicate that cell death may be a normal feature of inner cell mass development. Small, apparently empty vesicles could be seen in the mouse, cow and human blastocysts and these may be the result of utilization of energy stores. Large vesicles seen in the human and bovine trophoblast cells contained flocculent granular material similar to that seen in the blastocoele. Pinocytotic activity was observed on the blastocoelic surface of the trophoblast cells, and small clusters of vesicles containing granular material were frequently seen coalescing. The direction of pinocytosis could not be determined from our micrographs and these large vesicles could be involved in secretion of fluid into the cavity of these rapidly expanding blastocysts. The abundance of long microvilli on the outer surface of polar trophoblast cells, reported here for the human blastocyst, has also been observed in hatched rhesus monkey blastocysts (Hurst et al., 1978).

Mitochondria in the human blastocyst appeared more elongated, electron transluscent and had an increased number of transverse cristae compared to the mouse and bovine blastocysts. This may indicate increased metabolic activity of the human blastocyst as mitochondrial development is well correlated with metabolic activity (Stern, Biggers \& Anderson, 1971).

The structural integrity of this hatched human blastocyst is an encouraging indication that developmental viability of human embryos may be retained for quite long periods of time in the culture conditions described. This is particularly important when much shorter times are employed for in-vitro culture (Trounson et al., 1981, 1982). However, apparently normal ultrastructural observations do not necessarily indicate complete viability because there are many essential biochemical components which cannot be detected by this method of embryo evaluation. However, the fertilization and culture of a human embryo under conditions identical to those used in this study led to the establishment of a normal pregnancy after transfer of a 4-cell embryo (Trounson et al., 1981) and this pregnancy has now resulted in the birth of a normal infant. This study has confirmed that while the embryos of different mammalian species have a characteristic ultrastructure, there are some common structural features of development. Ultrastructural comparison of human embryos with those of other species can yield information on the developmental status and morphological normality of these embryos.

We thank Mr Ken Old of Devondindi Transplant Co. for provision of bovine blastocysts and Ms Anne Pugh for technical assistance.

\section{References}

Blandau, R.J. (1971) The Biology of the Blastocyst. University of Chicago Press.

Brand, A., Trounson, A.O., Aarts, M.H., Drost, M. \&
Zaayer, D. (1978) Superovulation and non-surgical embryo recovery in the lactating dairy cow. Anim. Prod. 26, 55-60. 
Fdwards, R.G. (1973) Physiological aspects of human ovulation, fertilization and cleavage. J. Reprod. Fert., Suppl. 18, 87-101.

Edwards, R.G. (1980) Conception in the Human Female. Academic Press, London.

Edwards, R.G., Steptoe, P.C. \& Purdy, J.M. (1980) Establishing full-term pregnancies using cleaving embryos grown in vitro. Br. J. Obstet. Gynaec. 87, 737-756.

Enders, A.C. (1971) The fine structure of the blastocyst. In The Biology of the Blastocyst, pp. 71-94. Ed. R. J. Blandau. University of Chicago Press.

Grant, P., Nilsson, B.O. \& Bergstrom, S. (1977) The cysts developed in vivo and in vitro. J. exp. Zool. 182, 95-118.

Hoppe, P.C. \& Pitts, S. (1973) Fertilization in vitro and development of mouse ova. Biol. Reprod. 8, 420426.

Hurst, P.R., Jefferies, K., Eckstein, P. \& Wheeler, A.G. (1978) An ultrastructural study of preimplantation uterine embryos of the rhesus monkey. J. Anat. 126, 209-220.

Lopata, A., Johnston, I.W.H., Hoult, I.J. \& Speirs, A.L. ( 1980$)$ Pregnancy following intrauterine implantation of an embryo obtained by in vitro fertilization of a preovulatory egg. Fert. Steril. 33, 117-120.

McReynolds, H.D. \& Hadek, R. (1972) A comparison of the fine structure of late mouse blastocysts developed in vivo and in vitro. J. exp. Zool. 182.95-118.

Mohr, L.R. \& Trounson, A.O. (1980) The use of fluoresein diacetate to assess embryo viability in the mouse. J. Reprod. Fert. 58, 189-196.

Mohr, L.R. \& Trounson, A.O. (1981) Structural changes associated with freezing of bovine embryos. Biol. Reprod. 25, 1009-1025.
Nadijcka, M. \& Hillman, N. (1974) Ultrastructural studies of the mouse blastocyst substages. $J$. Embryol. exp. Morph. 32, 675-695.

Ozias, C.B. \& Stern, S. (1973) Glycogen levels of preimplantation mouse embryos developing in vitro. Biol. Reprod. 8, 467-472.

Pike, I.L. (1981) Comparative studies of embryo metabolism in early pregnancy. J. Reprod. Fert., Suppl. 29, 203-213.

Steptoe, P.C., Edwards, R.G. \& Purdy, J.M. (1971) Human blastocysts grown in culture. Nature, Lond. 229, 132-133.

Stern, S., Biggers, J.D. \& Anderson, E. (1971) Mitochondria and early development of the mouse. J. exp. Zool. 176, 179-192.

Tervit, H.R. \& Rowson, L.E.A. (1974) Birth of lambs after culture of sheep ova in vitro for up to 6 days. $J$. Reprod. Fert. 38, 177-179.

Trounson, A.O., Leeton, J.F., Wood, C., Webb, J. \& Kovacs, G. (1980) The investigation of idiopathic infertility by in-vitro fertilization. Fert. Steril. 34, 431-438.

Trounson, A.O., Leeton, J.F., Wood, C., Webb, J. \& Wood, J. (1981) Pregnancies in humans by fertilization in vitro and embryo transfer in the controlled ovulatory cycle. Science, N.Y. 212, 681-682.

Trounson, A.O., Mohr, L.R., Wood, C. \& Leeton, J.F. (1982) Effect of delayed insemination on in-vitro fertilization, culture and transfer of human embryos. J. Reprod. Fert. 64, 285-294.

Wintenberger-Torrès, S. \& Fléchon, J.E. (1974) Ultrastructural evolution of the trophoblast cells of the preimplantation sheep blastocyst from day 8 to day 18.J. Anat. 118, 143-153. 